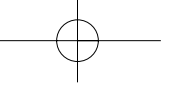

\title{
InTERnATIONAL CONFLICTS AND DECISION MAKING ON the Federal District COURTS*
}

\author{
Paul M. Collins, Jr., Daniel A. Norton, Kenneth L. Manning, \\ AND ROBERT A. CARP
}

The international environment influences domestic politics, particularly during times of war. The traditional governmental response to such crises is to curtail the civil rights and liberties of Americans in the name of national security. Often, challenges to these restrictive policies find their way into the federal court system. However, little is known about the systematic effects of these conflicts on the choices jurists make. To redress this deficiency, we investigate whether international conflicts influence the decision making of federal district-court judges by examining the choices those judges make during periods of both war and peace. In addition, we consider whether male and female jurists react differently to periods of international unrest. We find that female judges do respond to wars, deciding cases more liberally than in peacetime, but male judges exhibit no response. As such, our results suggest that gender is an important consideration in evaluating the judicial response to war.

$\Gamma$ he current U.S. war on terror has had a dramatic influence on many aspects of domestic politics. None, however, have been as controversial as the debate regarding the potential erosion of individual rights and liberties. In light of the Patriot Act, and other governmental responses to the war on terror, many academics, politicians, and pundits have speculated on what effect the current crisis may have on the level of freedoms enjoyed by the American citizenry. To be sure, the debate regarding the trade-off between freedom and security is hardly new to the postSeptember 11th era. The general consensus is that, during times of war, the government tends to err on the side of national security to the detriment of individual freedoms (e.g., Linfield, 1990; Rehnquist, 1998; Tushnet, 2003). Historical evidence suggests this sentiment is not unfounded. Supporting this perspective, for example, analysts point to a variety of war-related activities, including the suspension of habeascorpus rights during the Civil War (e.g., Neely, 1992), the Palmer Raids following World War I (e.g., Duggan, 2005), the internment of Japanese-Americans during World War II (e.g., Robinson, 2001), the attempted suppression of the publication of the Pentagon Papers during the Vietnam War (e.g., Rudenstine, 1996), and, most recently, the increase in governmental surveillance associated with the war on terror (e.g., Nelson, 2004). A more contentious issue, however, involves the role of the judiciary in determining the balance between liberty and security. It has been suggested that, during times of international crisis, the courts—-the very institutions designed to

\footnotetext{
* We are indebted to Bob Howard, Wendy Martinek, Dave Mason, Lisa Solowiej, Steve Wasby, and the anonymous reviewers for helpful feedback on this and related research and to Chris Nicholson for his exemplary research assistance. We remain solely responsible for any remaining errors in fact or judgment.
} 
protect individual freedoms from an overzealous government - often stand idly by and may even aid in the erosion of individual rights (e.g., Friedman and Neuborne, 1972; Linfield, 1990; Lobel, 2002; Rehnquist, 1998; Rostow, 1945; Tushnet, 2003).

Although receiving general support from the academic community, the notion that courts allow civil rights and liberties to be curtailed during war, especially those very rights it would otherwise protect, is supported primarily through anecdotal evidence. Cases such as Korematsu v. United States (1944), in which the Supreme Court upheld an executive order excluding citizens of Japanese ancestry from areas considered critical to national security, are often treated as definitive evidence that the "crisis thesis" is, in fact, correct (e.g., Garvin, 1999; Rostow, 1945; cf. Barak, 2002; Fortas, 1968). Yet, the idea that the judiciary allows civil rights and liberties to be eroded during periods of international crisis cannot be confirmed by a single case, or even a handful of similar cases. Instead, the crisis thesis requires the analysis of empirical patterns over time regarding judicial decisions in civil rights and liberties cases during periods of both war and peace. Despite the fact that literally hundreds of articles and books are dedicated to the discussion of the crisis thesis (for an overview, see, e.g., Epstein et al., 2005), few scholars have sought to test the empirical validity of the crisis thesis utilizing this straightforward rule of inference. Of those that have, Epstein et al. (2005) find that the Supreme Court is 10 percent more likely to render a conservative decision during periods of war (for those cases unrelated to the war), while Clark (2006) finds that courts-of-appeals judges behave similarly with respect to criminal defendants during times of international conflict. Our motivation in the current project is to add to this significant, though limited, line of inquiry by examining the effect of wars and crises on the decision making of federal district-court judges.

We believe that subjecting the crisis thesis to empirical validation in the federal district courts is significant for a number of reasons. First, although the crisis thesis was developed in relation to the Supreme Court, its basic logic is equally applicable to lower courts. As such, the analysis of federal district-court decision making provides the opportunity to investigate the relevance of this theory at a different level of the federal court system. Moreover, because these courts occupy a position at the front door of the federal judicial system, the timeliness of their rulings, relative to appellate courts, makes them especially appropriate for review.

Second, because the federal district courts handle the vast majority of federal litigation in the United States, examining the applicability of the crisis thesis in these courts allows for the evaluation of its pertinence in the federal courts most Americans come into contact with. Given that the likelihood of Supreme Court review is practically nonexistent for district-court judges, in a very real way the district courts' point of view on civil rights and liberties during wartime is more meaningful than the Supreme Court's perspective in these cases. For example, in 2004, the Supreme Court disposed of only 87 cases, compared to 317,382 cases in the district courts (Mecham, 2005).

Third, due to the relatively high level of gender diversity on the federal district courts (e.g., Solberg and Bratton, 2005), examining decision making on these courts 


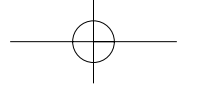

INTERNATIONAL CONFLICTS AND DeCISION MAKING

offers the unique opportunity to test a theory largely ignored in the judicial crisis literature-namely, that female and male jurists might respond differently to periods of international unrest, reflecting gender differences in attitudes toward war among the citizenry at large (e.g., Clarke et al., 2004; Conover and Sapiro, 1993; Wilcox, Hewitt, and Alsop, 1996).

Finally, and most important, analyzing the behavior of district-court judges is important because of the significant policy-making role these judges play (e.g., Cooper, 1988; Schubert, 1965). Although their decision making is theoretically constrained by appellate courts, the growing emergence of legal questions for which these appellate courts have provided limited guidance gives federal district-court judges substantial leeway to shape the direction of public policy in the United States (Carp and Rowland, 1983:4). For example, district-court judges regularly grapple with disputes evolving from the government's war-related activities, including compensation for the internment of Japanese-Americans (e.g., Hohri v. United States, 1984), alien detention in Guantanamo Bay (e.g., Khalid v. Bush, 2005), judgments against members of Al Qaeda for injuries suffered by U.S. soldiers serving in Afghanistan (e.g., Morris v. Khadr, 2006), in addition to restrictions on free-expression rights targeting speech both supporting (e.g., Grzywna v. Schenectady Central School District, 2006) and opposing (e.g., Hodsdon v. Buckson, 1970) the government's crisis-related activities. In short, given the considerable role federal district-court judges occupy in American government, assessing the applicability of the crisis thesis to these yet unexamined courts will add to our understanding of the judiciary's role during periods of international unrest.

The article proceeds as follows. In the next section, we develop our theoretical argument for why judges might behave differently in periods of war than in times of peace. Following this, we test our hypotheses by examining civil-rights-and-liberties cases decided in the federal district courts from 1938 to 2004. Next, we investigate whether male and female jurists respond differently to international unrest, building on theoretical intuitions derived from the substantial public-opinion and international-relations literatures that demonstrate a gender gap in attitudes toward war. We conclude by discussing the implications of our results, both for how foreign affairs affect domestic actors and how judges and courts render their decisions.

\section{DOMESTIC REACTIONS TO INTERNATIONAL CONFLICTS}

The crisis thesis rests on the assumption that domestic politics can be influenced by the international environment (Gourevitch, 1978). This is certainly not a novel contention on our part, nor is it a new idea that international crises can significantly shape how domestic actors behave. The view most often espoused in the crisis literature is as follows. First, the United States becomes involved in an international conflict. Recognizing that the nation's well-being is jeopardized by an outside actor, the public makes an effort to appear united as their government confronts the common threat (e.g., Gelpi, 1997). The president, as the most visible symbol of the 
nation's common interest, benefits from this amplified cohesion through increased approval ratings as a result of Americans' efforts to show the foreign opposition that they are of a like mind (e.g., Erikson, Luttbeg, and Tedin, 1980; Mueller, 1970; Oneal and Bryan, 1995; Russett, 1990; but see Lian and Oneal, 1993). Next, government officials develop policy responses to the national-security threat that often involve suppressing civil rights and liberties at home (e.g., Duggan, 2005; Heymann, 2002; Tushnet, 2003). Congress, in an effort both to avoid drawing the ire of a public that has rallied around the president and to present a united front (e.g., Schultz, 1998), recognizes the executive as the nation's voice in foreign affairs (e.g., Hinckley, 1994; Koh, 1996) by endorsing the president's crisis-related prerogatives (e.g., Edwards, 1976; Fleisher and Bond, 1988; Meernik, 1993; Peterson, 1994; Prins and Marshall, 2001; Wildavsky, 1966; but see Fleisher et al., 2000). Once these policies take effect, members of the public bring lawsuits challenging these governmental actions as unconstitutionally restricting their civil rights and liberties, ultimately giving the judicial branch final say on the matter (although Congress can have "last licks" by stripping federal courts of jurisdiction or overriding statutory decisions, while the president can indifferently enforce judicial decisions).

This elemental account of the domestic response to international crises is important for two reasons. First, it makes clear that international crises influence the behavior of domestic political actors, both elite and nonelite. Second, it offers a theoretical foundation for the idea that the judiciary's response to international crises might mirror that of the public and Congress. Though they hold a special place in society, federal judges are, after all, citizens too, and there is no reason to assume that they are immune from the nationalistic tides that swell during periods of international crisis (e.g., Rossiter, 1976:91). Therefore, we argue that international crises are likely to elicit a response from the courts that echoes the reactions of the public and Congress. This response is expected to be structured by the same factors that shape the actions of the other actors we have discussed; specifically, the desire to appear united in the face of an international threat. Supporting this perspective, former Chief Justice Rehnquist (1998) has argued that, like other members of society, Supreme Court justices have no desire to harm the nation's war efforts. Similarly, comments made by federal District Court Judge William Young (D. MA.) at the sentencing hearing of the "shoe bomber," Richard Reid, are clearly suggestive of embracing an us/them mentality in response to a foreign threat.

You are not an enemy combatant, you are a terrorist. You are not a soldier in any army, you are a terrorist. To call you a soldier gives you far too much stature. .. . You are a terrorist, and we do not negotiate with terrorists. We hunt them down one by one and bring them to justice. ... You see that flag, Mr. Reid? That's the flag of the United States of America. That flag will fly there long after this is all forgotten. That flag still stands for freedom. You know it always will (quoted in Belluck, 2003:13). 
Given these comments, and consistent with the majority of the judicial crisis literature (e.g., Epstein et al., 2005:4), we expect that the judiciary's response to international crises will personify those of the public and Congress. Although it is reasonably well established that the public rallies by showing greater support for the president, while the legislature rallies by increasing its deference to the executive's agenda, the question remains: how do the courts rally? The most common version of the crisis thesis suggests that judges' desire to maintain the appearance of national unity (to rally) will result in support for governmental efforts to curtail the civil rights and liberties of the citizenry (e.g., Clark, 2006; Epstein et al., 2005; Linfield, 1990; Lobel, 2002; Rostow, 1945; Tushnet, 2003). Such is the case for two reasons.

First, it is important to recognize that civil rights and liberties cases often come before the courts precisely because of specific actions taken by the government during periods of crisis. After all, it was the government that suspended habeas corpus during the Civil War; it was the government that instituted the Alien and Sedition Acts; it was the government that oversaw the internment of Japanese Americans during World War II; and it is the government that is currently scaling back Americans' civil rights and liberties under the Patriot Act. Moreover, these actions are often presented by the government as measures necessary to handle the crisis facing the country. Therefore, if the courts were to rule in favor of upholding the civil rights and liberties involved in any given case, they could potentially undermine the government's effort to deal with the crisis. This creates a strong incentive for judges to support governmental policies that curtail rights and liberties. As Downs and Kinnunen (2003:390) note, "The provisions relating to the war powers of the executive and legislative branches and a long line of Supreme Court precedents indicate that the government possesses greater power in times of war than in times of peace, and that the concomitant balance between liberty and security may properly shift." Further, in their efforts to promote the government's ability to manage a crisis, judges can altogether avoid hearing cases related to the government's war-related activities by invoking the political-questions doctrine (e.g., Adler, 1996; Franck, 1992; King and Meernik, 1999). In so doing, judges are capable of tacitly supporting governmental policies by ensuring that challenges to those policies are kept out of the federal court system. This is a particularly relevant point with regard to the study of district courts since these adjudicative bodies occupy a position at the front-door of the federal judiciary and, thus, provide the initial determination as to whether a particular case is ripe for federal court review.

Second, court rulings in these cases can also shape the nation's unity, or more accurately, the appearance of national unity, regardless of whether the cases are directly related to the government's crisis-related policies that curtail civil rights and liberties. For example, many civil rights and liberties cases that come before the courts specifically deal with individuals' criticisms of government actions or officials, but do not explicitly challenge restrictive governmental policies related to the war 
effort. This may be particularly true during periods of international crisis because citizens are increasingly likely to voice their opposition to the government's tactics. Though seemingly protected by the Constitution, large protests and other forms of dissent against the government can certainly harm the appearance of unity. To the extent that the courts are interested in helping the nation appear united, we expect they will be less likely to support these freedoms during periods of crisis. Further, criminal cases that are decided during, but are unrelated to, an international crisis might result in increased judicial deference to the executive branch by siding with the federal prosecution (e.g., Clark, 2006). In so doing, federal judges indicate their willingness to support the executive's policies as the line between domestic and international affairs blurs. For example, studies indicate that federal district-court judges (Ducat and Dudley, 1989), court-of-appeals jurists (Randazzo, 2004), and Supreme Court justices (King and Meernik, 1999; Yates and Whitford, 1998) are more likely to defer to the federal government on issues implicating foreign affairs than in purely domestic cases. Moreover, as Epstein et al. (2005:27) point out, judges may respond to international crises by altering their standards for adjudicating allegations of the suppression of free-expression rights, in addition to modifying their definitions of reasonable searches and seizures, regardless of whether the case is explicitly tied to the government's war effort. Consistent with this view, we hypothesize that federal district-court judges will rule more conservatively in civil-rights-and-liberties cases during periods of international conflict than in periods of peace.

Of course, it is equally important to note that scholars, and to a lesser extent judges themselves, have suggested an alternative perspective of the judicial branch's behavior during periods of international crisis. This view suggests that, rather than defer to the democratically elected branches and sanction the suppression of Americans' civil rights and liberties during periods of international crisis, the courts should, and do, instead "rebuke the legislatures and executive authorities when, under stress of war, emergency, or fear of Communism or revolution, they have sought to suppress the rights of dissenters" (Fortas, 1968:22; see also Barak, 2002; Klinkner and Smith, 1999; Koh, 2002). A classic example of this is Chief Justice Taney's circuit court opinion in Ex Parte Merryman (1861), holding that President Lincoln's suspension of habeas corpus during the Civil War was unconstitutional (although Lincoln ignored Taney's decision only to have the Supreme Court strike down the president's power to suspend habeas corpus in the separate case of Ex Parte Milligan, 1866). In the federal district courts, a recent example is evident in U.S. v. Koubriti (2003), in which former Attorney General Ashcroft was judicially admonished for discussing pending litigation against three individuals suspected of having knowledge of the September 11th attacks, in spite of a judicial order that prohibited the public disclosure of information that might interfere with a fair trial or otherwise prejudice judicial proceedings. Writing for the court, Judge Gerald Rosen (E.D. MI.) (2003:726) explained: 
Despite his unquestioned duty to address the Nation on matters of public concern, and his more specific responsibility to keep the Nation informed of the Justice Department's efforts in the war on terror, the Attorney General has an equally vital and unyielding obligation, as the Nation's chief prosecutor, to ensure that defendants are accorded the fair trial guaranteed to them under our Constitution. In this case, this essential balance was jeopardized, even after the Court had issued specific warnings.

In essence, this view stems from the judicial branch's unique institutional place in American government. Because federal judges are seemingly insulated from public pressures, with no electoral or political accountability, they are in a distinctive position to actually protect the rights of Americans in the face of restrictions from the executive and legislative branches. For example, in Padilla v. Hanft (2005:690-91), District Court Judge Henry Floyd (D. S.C.), in granting Padilla's habeas-corpus petition, wrote that "the Court is of the firm opinion that it must reject the position posited by [the United States]. To do otherwise would not only offend the rule of law and violate this country's constitutional tradition, but it would also be a betrayal of this Nation's commitment to the separation of powers that safeguards our democratic values and individual liberties." As this makes clear, Judge Floyd recognizes that the judiciary may have a special responsibility to defend the rights of individuals, even when this forces the courts to oppose the elected branches of government. If this alternative view of the courts comports with reality, we expect that periods of international crisis will decrease the likelihood of observing judges deferring to the elected branches in their attempts to suppress civil rights and liberties based on their perceived role in protecting the rights of the American citizenry. As such, this version of the crisis thesis predicts that, during international conflicts, judges will be less likely to render conservative decisions.

Finally, it is imperative to identify a third view corresponding to judicial decision making during wartime that predicts that international crises will have no influence on judicial decision making because the courts may simply continue on with business as usual (e.g., Gross, 2003:1043). This variant of the crisis thesis suggests that liberal judges will continue to support the civil-rights-and-liberties claimant, while conservative judges will continue to support limitations on civil-rights-and-liberties claims, regardless of whether the country is engaged in an international conflict. Indeed, this appears to be the position advanced by Supreme Court Justice Jackson in West Virginia v. Barnette (1943:642), in which he noted during the heat of World War II: "If there is any fixed star in our constitutional constellation, it is that no official, high or petty, can prescribe what shall be orthodox in politics, nationalism, religion, or other matters of opinion or force citizens to confess by word or act their faith therein. If there are any circumstances which permit an exception, they do not now occur to us" (emphasis added). 


\section{RESEARCH METHODOLOGY AND DATA}

To subject these rival hypotheses involving the crisis thesis to empirical validation, we collected data from the decisions of U.S. district-court judges in civil-rights-andliberties cases (including criminal-justice disputes) published in the Federal Supplement from 1938 to 2004, excluding cases decided by three-judge panels. We recognize that the inclusion of only published decisions may potentially bias the findings in this study, in that differences might exist with respect to unpublished versus published decisions. Nonetheless, because published opinions are most likely to reflect those disputes that have substantial import beyond the parties directly involved in a case (e.g., Rowland and Carp, 1996; Swenson, 2004), we believe these decisions are well-suited for investigating the crisis thesis, with the caveat that our results may not be applicable to unpublished opinions. Further, since unpublished decisions available on Westlaw and Lexis are incomplete, particularly before 1986, and because access to these early opinions at the district courts is limited (e.g., Sisk, Heise, and Morriss, 2004:537), the inclusion of unpublished opinions would likely introduce substantial temporal bias into our analyses.

This dataset includes more than 48,000 cases handled by more than 1,700 judges. Selected cases encompass litigation involving alien petitions, criminal rights, discrimination claims, freedom of expression and religion, habeas-corpus claims, military exclusion, and the right to privacy. In an effort to include only those issue areas that might theoretically implicate an international crisis, we examined cases involving each of the issue areas discussed above to locate both federal district-court and Supreme Court cases that evolved from military- and conflict-related activities. Because we found one (or more) cases falling into these issue areas, all cases falling under that issue area were included in the analyses. ${ }^{1}$ Thus, the cases under analysis

1 In particular, we examined each issue area to identify conflict-related cases, such as those disputes involving national-security threats, the suppression of political speech that is related to an international conflict, and the rights of military personnel during wartime. We were able to locate cases matching all of the categories described above. Our logic in making this distinction is that, given the existence of a war-related precedent within a particular issue area, cases falling within that general issue area may potentially receive dissimilar treatment depending on whether they are decided during war or peace (e.g., Garvin, 1999:707; Gross, 2003:1095; May, 1989:264).

The following cases constitute a partial, but representative, sample of disputes utilized to determine whether a particular issue area might theoretically receive disparate treatment as a result of being decided in times of international conflict. We included cases involving habeas corpus in our dataset, given the Supreme Court precedent of Ex Parte Milligan (1866), which involved the suspension of habeas-corpus rights during the Civil War. We incorporate cases involving alien petitions due to the existence of United States v. Herberger (W.D. WA. 1921), a district-court case centering on the government's attempt to revoke a certificate of naturalization based on the government's allegation that the defendant refused to renounce his allegiance to the German emperor. Cases involving free expression were included based on Schenck $v$. United States (1917), which implicated the government's attempt to prosecute Schenck for distributing leaflets urging resistance to the draft in violation of the Espionage Act. Disputes involving criminal activity were included as a partial function of United States v. Mulligan (N.D. N.Y. 1920), a criminal case concerning the defendant's refusal to provide the government with records regarding sugar sales in violation of the Lever Act, which compelled business owners to provide the government with sales records on certain goods deemed essential to national security and defense. Controversies 


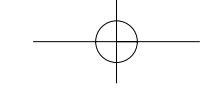

INTERNATIONAL CONFLICTS AND DeCISION MAKING

involve disputes that are both related and unrelated to wars and crises. This allows us to evaluate the extent to which international conflicts might influence judicial decision making in federal district courts for a broad range of controversies involving civil rights and liberties (e.g., Epstein et al., 2005).

The exact coding of our dependent variable and independent variables is discussed in the Appendix. Our dependent variable captures the ideological direction of the decision. We created this variable based on a well-established methodology (e.g., Carp and Rowland, 1983; Rowland and Carp, 1996; Manning, Carroll, and Carp, 2004; see also Songer, 1999; Spaeth, 2003). Liberal decisions involving criminal rights and habeas-corpus claims support the rights of the criminally accused, while conservative decisions are in favor of the government. For cases involving freedom of expression and religion, liberal decisions favor the litigant alleging a violation of these freedoms, while conservative decisions favor restrictions on free speech and religion. Liberal decisions related to discrimination are supportive of the litigant claiming discrimination, while conservative decisions are the opposite. Decisions that support the litigant alleging a violation of privacy rights are coded as liberal, while decisions that favor limitations on privacy rights are coded as conservative. For cases involving alien petitions, liberal decisions support the petitioner, while conservative decisions favor the government. Liberal decisions in military-exclusion cases favor the individual claiming, for example, a violation of constitutional rights as a result of military-exclusion orders, while conservative decisions favor the government. Since our dependent variable is dichotomous, we employ a probit model, estimated using robust standard errors.

The primary variable of interest in our analysis is whether the United States was involved in an international conflict. On the one hand, we might classify conflicts only as congressionally declared wars (i.e., World War II) or congressionally authorized uses of force (e.g., Vietnam, Persian Gulf War). On the other hand, along with these, we might include expert-identified major international crises (e.g., the Berlin Blockade, the Korean War, the Cuban Missile Crisis, the Iran Hostage Crisis). Following Epstein et al. (2005) we opted for the latter strategy. We did so because there is no theoretical reason to include the former conflicts at the expense of the latter. In other words, we have no expectation that judges will consider World War II to be influential on their decisions, but not the Vietnam War. Further, by using the classification scheme adopted by Epstein et al. (2005) we maximize our ability to compare our results with theirs. Accordingly, we identify our conflicts as follows: Wars include World War II (12/7/41-8/14/45), the Korean War (6/27/50-7/27/53), the Vietnam War (2/7/65-1/27/73), the Persian Gulf War (1/16/91-4/11/91), and the war in Afghanistan (10/7/01-3/14/02); Crises include the Berlin Blockade (6/24/48-5/12/49), the Cuban Missile Crisis (10/16/62-11/20/62), the Iran Hostage

implicating freedom of religion are included based on Gobitis v. Minersville School District (E.D. PA. 1937), in which a district court adjudicated whether a school district's policy requiring students to salute the American flag violated the First Amendment. 
Crisis (11/4/79-1/20/81), and the War on Terror (9/11/01-12/31/04, the last date in our data). ${ }^{2}$

In the statistical models that follow, we estimate the effects of wars and crises in the same model specification, as well as in separate model specifications. We do this because there are considerable differences between wars and crises (e.g., Tushnet, 2003:279). First, many of the conflicts classified as wars resulted in substantial government actions curtailing civil rights and liberties, while most of the crises did not. For example, government reactions to wars include the internment of JapaneseAmericans (World War II), the Red Scare (Korean War), and the widespread suppression of political speech (Vietnam War). With the exception of the War on Terror, we are hard-pressed to identify similar government actions with respect to crises. Second, the duration of wars and crises exhibit widespread disparity: the average length of conflicts categorized as wars is 1,126 days, compared to 502 days for crises. Inasmuch as the duration of a war is associated with perceptions of its severity (e.g., Vasquez, 1987), there is good reason to believe that judges might respond differently to short-term shocks to the nation's foreign affairs than to prolonged conflicts. Finally, these conflicts are marked by substantial differences in the number of warrelated deaths. For example, more than 400,000 American casualties are associated with World War II, while 58,000 American deaths stemmed from the Vietnam War. In comparison, those conflicts classified as crises resulted in far fewer casualties, American or otherwise (Department of Defense, 2007). Because judges, like other Americans, are likely to view conflicts associated with relatively large numbers of battle deaths as especially salient (e.g., Gartner, Segura, and Barratt, 2004), we believe this further reinforces our decision to treat wars and crises separately.

To tie wars and crises to the judges' decision calculi, we use the date of the decision according to the Federal Supplement. While we recognize that a judge might author his or her opinion days to weeks in advance of the date that the opinion is released, the only date available from the federal reporters is the date of the decision. Further, since a judge can theoretically withhold or alter an opinion at any given point until the decision is announced (e.g., Clark 2006), we believe this choice is most appropriate, while recognizing that this choice is not without its problems. For example, a judge might reach an opinion that was entirely driven by the crisis thesis, but publish that opinion some days after a conflict ends. Accordingly, we experimented with a variety of alternatives for tying the beginnings and ends of conflicts to opinions, none of which altered the substance of the findings presented here.

To account for more well-established influences on district-court decision making, we include a number of control variables in the models. First, following from the substantial literature demonstrating that attitudes influence the choices judges make

\footnotetext{
2 The dates for wars were obtained from Epstein et al. (2005:47), while the dates of crises were gathered from Brecher and Wilkenfeld (2004). In our data, 20 percent of decisions were handed down while the country was engaged in wars, and 10 percent of cases were disposed of during crises.
} 
(e.g., Carp and Rowland, 1983; Carp, Manning, and Stidham, 2004; Segal and Spaeth, 1993), we include a Party variable that captures the party affiliation of the president who appointed each judge in the data. We expect that judges appointed by Republican presidents will be more likely to render conservative decisions than judges appointed by Democratic presidents, consistent with a voluminous body of previous research (for a review, see Pinello, 1999). While we recognize that this is an imperfect surrogate for judicial ideology, it nonetheless has been shown to have substantial face validity. For example, in a meta-analysis of eighty-four articles, books, dissertations, and conference papers on federal-court decision making, Pinello concludes that "party is a dependable measure of ideology on modern American courts. Democratic judges are indeed more liberal on the bench than their Republican counterparts" (1999:243). This corroborates the fact that, with some notable exceptions, presidents are successful at appointing like-minded judges to the federal bench who render decisions consistent with the policy goals of their appointing presidents (e.g., Carp, Manning, and Stidham, 2004; Segal, Timpone, and Howard, 2000).

To control for gender differences that might implicate judicial decision making in cases involving civil rights and liberties (e.g., Gryski, Main, and Dixon, 1986; Manning, Carroll, and Carp, 2004; Peresie, 2005), we include a Gender variable. We expect that female judges will be more likely to render liberal decisions than their male counterparts as a result of women's collective experience overcoming discrimination, resulting in increased empathy for underdogs (e.g., criminal defendants, civilliberties claimants) in the judicial system (e.g., Gruhl, Spohn, and Welch, 1981; Songer and Crews-Meyer, 2000). We also include a variable that captures a judge's Minority status. Based on the notion that civil-rights advocates pressed for minority judges to contribute to a more equitable society (e.g., Welch, Combs, and Gruhl, 1988:126), and the expectation that minority judges would act to reduce the vestiges of inequality, racial and otherwise (e.g., Crockett, 1970; Sisk, Heise, and Morriss, 1998), we expect that minority judges will be more likely to hand down liberal decisions in civil-rights-and-liberties cases, as compared to their white counterparts. ${ }^{3}$

To capture the fact that federal district courts sit at the bottom of the judicial hierarchy, and might be constrained by the ideological proclivities of the circuit court of appeals under which they operate and the Supreme Court (e.g., Baum, 1980), we control for the preferences of these courts. As a proxy for their ideological makeup, we utilize the proportion of Republicans, as identified by the party affiliation of the president who appointed each judge or justice, serving on the Supreme Court and the supervisory circuit court of appeals pertinent to each district court. While we acknowledge that these are imperfect measures of appellate-court preferences, they

\footnotetext{
3 In the data under analysis, 63.5 percent of female judges were appointed by Democratic presidents and 36.5 percent were appointed by Republican presidents, while 64.6 percent of minority judges were appointed by Democrats and 35.3 percent were appointed by Republicans. Thus, while a majority of both female and minority judges were appointed by Democrats, it is inappropriate to view these variables as surrogates for affiliation with the Democratic Party.
} 


\begin{tabular}{|c|c|c|c|c|c|}
\hline \multirow{3}{*}{$\begin{array}{l}\text { Predictor } \\
\text { Wars }\end{array}$} & \multicolumn{4}{|c|}{$\begin{array}{l}\text { Table } 1 \\
\text { Effects of Wars and Crises on Decision Making } \\
\text { in the Federal District Courts, 1938-2004 }\end{array}$} & \\
\hline & \multicolumn{2}{|c|}{ Model I } & Model II & \multicolumn{2}{|c|}{ Model III } \\
\hline & \multirow[t]{2}{*}{$\begin{array}{l}-0.027 \\
(0.017)\end{array}$} & \multirow[t]{2}{*}[-1.0]{} & & $\begin{array}{l}-0.027 \\
(0.018)\end{array}$ & {$[-1.0]$} \\
\hline Crises & & & $\begin{array}{l}-0.002 \\
(0.020)\end{array}$ & $\begin{array}{l}-0.004 \\
(0.020)\end{array}$ & {$[-0.1]$} \\
\hline Party & \multicolumn{2}{|c|}{$\begin{array}{l}0.289^{\star \star}\left[+10.6^{\star \star}\right] \\
(0.013)\end{array}$} & $\begin{array}{l}0.291^{* *}\left[+10.7^{* *}\right] \\
(0.013)\end{array}$ & \multicolumn{2}{|c|}{$\begin{array}{l}0.288^{* *}\left[+10.6^{* *}\right] \\
(0.013)\end{array}$} \\
\hline Gender & $\begin{array}{l}-0.057^{*} \\
(0.024)\end{array}$ & {$\left[-2.2^{*}\right]$} & $\begin{array}{ll}-0.055^{*} & {\left[-2.1^{\star}\right]} \\
(0.024) & \end{array}$ & $\begin{array}{l}-0.056^{*} \\
(0.023)\end{array}$ & {$\left[-2.2^{*}\right]$} \\
\hline Minority & $\begin{array}{l}-0.113^{\star *} \\
(0.025)\end{array}$ & {$\left[-4.4^{\star *}\right]$} & $\begin{array}{l}-0.112^{* *} \\
(0.025)\end{array}$ & $\begin{array}{l}-0.112^{* *} \\
(0.025)\end{array}$ & {$\left[-4.4^{\star *}\right]$} \\
\hline $\begin{array}{l}\text { Supreme Court } \\
\text { Preferences }\end{array}$ & $\begin{array}{l}-0.536^{\star *} \\
(0.045)\end{array}$ & {$\left[-3.7^{\star *}\right]$} & $\begin{array}{ll}-0.513^{* *} & {\left[-3.5^{\star \star}\right]} \\
(0.042) & \end{array}$ & $\begin{array}{l}-0.536^{* *} \\
(0.045)\end{array}$ & {$\left[-3.7^{\star \star}\right]$} \\
\hline $\begin{array}{l}\text { Circuit Court } \\
\text { Preferences }\end{array}$ & $\begin{array}{c}0.071^{*} \\
(0.038)\end{array}$ & {$\left[+0.5^{*}\right]$} & $\begin{array}{c}0.079^{*} \\
(0.037)\end{array}$ & $\begin{array}{r}0.071^{*} \\
(0.038)\end{array}$ & {$\left[+0.6^{\star}\right]$} \\
\hline Constant & $\begin{array}{l}0.395^{\star *} \\
(0.039)\end{array}$ & & $\begin{array}{l}0.372^{\star *} \\
(0.036)\end{array}$ & $\begin{array}{l}0.396^{* *} \\
(0.039)\end{array}$ & \\
\hline Wald $X^{2}$ & $1,513.9^{* *}$ & & $1,514.8^{* *}$ & $1,513.9^{* *}$ & \\
\hline $\mathbf{N}$ & 48,025 & & 48,025 & 48,025 & \\
\hline \multicolumn{6}{|c|}{$\begin{array}{l}\text { Entries are probit coefficients. Numbers in parentheses indicate robust standard errors. Marginal } \\
\text { effects are reported in brackets. Marginal effects were calculated altering the variables of interest } \\
\text { from } 0 \text { to } 1 \text { for dichotomous variables and from the mean to one standard deviation above the mean } \\
\text { for continuous variables, holding all other variables at their mean or modal values. Dependent vari- } \\
\text { able indicates the ideological direction of the decision }(1=\text { conservative, } 0=\text { liberal). Models include } \\
53 \text { region-specific dummy variables (results not shown). }{ }^{*} p<.05,{ }^{* *} p<.001 \text { (one-tailed tests). }\end{array}$} \\
\hline
\end{tabular}

nonetheless serve as a reasonable proxy for district-court judges' perceptions of the ideological bent of the appellate bench (e.g., Pinello, 1999). If the district courts follow the ideological preferences of these higher courts, we expect the signs of the Supreme Court Preferences and Circuit Court Preferences variables will be positive in direction, indicating that, as the number of Republican judges serving on these courts increases, so too will the likelihood of observing a conservative decision. Finally, in order to account for region-specific influences on federal district court decision making, we include a dummy variable for each state, territory, and possession in the model, save one. The inclusion of these variables allows us to capture regional differences that are attributable to state-specific political values, dissimilar judicial socialization effects, and any cross-state variation in district-court dockets (Carp and Rowland, 1983:84-117). 
Before discussing the results of our statistical models, it is important to note that the dominant objective of our study is to test for the possible influence of wars and crises on decision making in the federal district courts, not to offer an integrated model of judicial choice. Numerous studies have identified a seemingly innumerable variety of variables that may, in any given context, influence judicial decisions. Rather than attempting to construct a comprehensive decision-making model in this article, our more modest goal is to investigate the extent to which periods of international conflict influence the decision making of federal district-court judges.

\section{EMPIRICAL RESULTS}

Table 1 reports the results of our models that estimate the effect of international conflicts on decision making in the federal district courts. Model I estimates the influence of wars only, Model II reports the results considering only crises, and Model III estimates wars and crises in the same model specification. We find no support for the influence of either wars or crises on federal district-court decision making, regardless of whether they are considered separately from each other or are included in the same model. In each model, the coefficients associated with the Wars and Crises variables fail to attain statistical significance at conventional levels. The strongest support for the influence of conflicts on district-court decision making is provided by Models I and III. In those models, the effect of wars is significant at the 0.07 level. However, while marginally significant, the substantive effect of wars is almost nonexistent. In particular, the results indicate that, holding all other variables at their mean or modal values, federal district-court judges are 1 percent more likely to render liberal decisions during periods of war than in times of peace. Thus, while it does provide some support for the contention that judges appear less willing to endorse restrictions on civil rights and liberties when the nation is embroiled in an international conflict as opposed to periods of tranquility, it also illustrates that this effect, while borderline statistically significant, is substantively devoid of any real meaning. This suggests that extant perceptions concerning judicial opposition to-or support for-government attempts to curtail the civil rights and liberties of Americans during wartime are not well supported by empirical data, at least in the federal district courts. In short, rather than altering their behavior due to a foreign threat as the crisis thesis predicts, district-court judges are best characterized as continuing on with business as usual.

Turning now to the control variables, we find substantial support for the contention that judicial ideology plays an important role in federal district-court decision making. In particular, as compared to a judge appointed by a Democratic president, a Republican-appointed judge is 11 percent more likely to render a conservative decision. In addition, our results indicate that significant differences exist between minority and nonminority jurists: female judges are 2 percent more likely to rule in the liberal direction than male judges, while white judges are 4 percent more likely to rule in the conservative direction than nonwhite jurists. Furthermore, these differences 
are especially enhanced when considering the additive effects of the variables in the model. For example, compared to a white-male judge who was appointed by a Republican, a minority-female judge who was appointed by a Democrat is 17 percent more likely to render a liberal decision.

The results regarding controls for the preferences of the Supreme Court and relevant circuit courts are especially interesting. We provide evidence that districtcourt judges are marginally constrained by the preferences of their supervisory court of appeals. Comparing a circuit court that is 50 percent Republican to one that is 75 percent Republican, a district judge is 1 percent more likely to cast a conservative vote in the latter scenario. However, district-court judges do not respond to the ideological makeup of the Supreme Court in the manner predicted: the addition of a single Republican Supreme Court justice actually decreases the likelihood of observing a conservative decision by 2 percent. Thus, district-court judges do not appear to follow the ideological proclivities of the Supreme Court. Rather, the addition of conservative justices - on both the circuit courts and Supreme Court-has very little substantive impact on decision making in the district courts (see also Baum, 1980). Although inconsistent with the hierarchy-of-justice literature, this apparent anomaly can nonetheless be explained in that the likelihood of reversal-which is the primary explanation for why lower-court judges alter their behavior based on the preferences of appellate courts (e.g., Songer, Segal, and Cameron, 1994:693) — is practically nonexistent for district judges. That is, given that district courts dispose of over 300,000 cases per year, while the Supreme Court disposes of less than 100, the probability that a decision will be accepted on appeal to the Supreme Court, much less reversed, is essentially zero. Moreover, since the courts of appeals overwhelmingly affirm those district-court decisions that are appealed (Songer, 1999), the probability of reversal in these courts is minimal (although higher than in the Supreme Court). In addition, because it is difficult for district judges to determine the preferences of circuit courts accurately, since circuit judges are randomly assigned to three-judge panels, the ability of district judges to engage in anticipatory behavior is severely limited. Comments by Judge Henry Graven (N.D. IA.) corroborate these explanations: "the people of this district either get justice here with me or don't get it at all. I've had a number of cases appealed over the years, but I've never been overruled. And I've never had a case go to the Supreme Court" (quoted in Rowland and Carp, 1996:1).

\section{IS THERE A GENDER GAP?}

We have subjected the most common version of the crisis thesis to empirical scrutiny, finding that, while a borderline statistically significant influence of war on federal district-court decision making exists, its substantive effects are minimal. While we could end our analysis here, we believe that it is fruitful to investigate the possibility that male and female judges might respond differently to periods of international unrest. While this consideration is largely absent from the judicial-crisis literature, it is well known to students of both public opinion (e.g., Clarke et al., 2004; Conover 


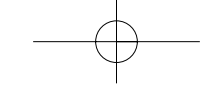

INTERNATIONAL CONFLICTS AND DeCISION MAKING

and Sapiro, 1993; Wilcox, Hewitt, and Alsop, 1996) and international relations (e.g., Goldstein, 2001; Keohane, 1989; Nincic and Nincic, 2002; Sylvester, 1994). Since we are analyzing decision making in the federal district courts, which are, by far, the most gender-diversified courts in the federal system, ${ }^{4}$ this provides an auspicious opportunity to investigate whether gender differences manifest themselves in the judicial response to conflicts.

To be sure, there is substantial evidence that men and women respond differently to international conflicts. For example, numerous studies indicate that American women are consistently less militaristic and more opposed to war than men (e.g., Conover and Sapiro, 1993; Nincic and Nincic, 2002; Shapiro and Mahajan, 1986), while Wilcox, Hewitt, and Allsop (1996) find that women are significantly less supportive of military actions in a cross-national analysis. Summarizing this literature in the American context, Page and Shapiro (1992: 295) conclude that "in practically all realms of foreign and domestic policy, women are less belligerent than men." While there are numerous theoretical explanations for this gender gap with respect to international conflicts, two are relevant here. First, many attribute the gender gap to women holding different values than men (e.g., Gilligan, 1982; Peterson, 1992). Specifically, dissimilar socialization and life experiences, which often result from roles imposed by society, are said to cause women to develop identities as caregivers. In turn, this is purported to move women to focus more on compassion than men, who are argued to be especially driven by competition and aggression. Second, this gender gap has been attributed to the notion that women are more likely to question aggressive government policies due to their shared struggle to achieve and maintain the same rights as men (e.g., Conover and Sapiro, 1993:1081; Cook and Wilcox, 1991). Under this conceptualization, the differences between male and female views of foreign conflicts stem, not from socialization effects, but from women's shared feminist consciousness. As Dietz (1985:23) notes, this social feminism involves a vigorous commitment to the democratic ideals of individual freedom, equality, nonviolence, and civic virtue. Under this account, we might expect female judges to show special sensitivity to the claims of litigants challenging restrictive governmental policies during wartime precisely because of feminist norms that reject hierarchy, government domination, and the use of force (Conover and Sapiro, 1993:1082). Indeed, the above results appear to support both of these explanations: regardless of whether the country is involved in an international conflict, female judges are more sympathetic to litigants challenging government attempts to suppress their civil rights and liberties, even when controlling for ideology.

While an important debate exists as to exactly what fuels this gender gap in attitudes toward war, we do not wish to engage it further. Rather, we seek to empirically

4 For example, Schafran (2005) reports that as of July 2005, 211 women served on federal district courts, compared to 57 on the courts of appeal and 2 on the Supreme Court. In our data, female judges comprise 7 percent of total observations ( 3 percent during war and 8 percent during peace). Thus, despite the fact that female judges authored only a small percentage of the opinions under analysis, sufficient observations exist to make estimation possible. 
Table 2

The Effect of Wars on the Decision Making of Male and Female Judges in the Federal District Courts, 1938-2004

$\begin{array}{lcc}\text { Predictor } & \text { Parameter Estimate } & \text { Marginal Effect } \\ \text { Wars } & -0.021 & -0.8 \\ & (0.018) & \\ \text { Party } & 0.289^{* *} & +10.7^{* *} \\ & (0.013) & \\ \text { Gender } & -0.046^{*} & -1.8^{*} \\ & (0.025) & \\ \text { Minority } & -0.111^{* *} & -4.3^{* *} \\ & (0.025) & \\ \text { Supreme Court } & -0.532^{* *} & -3.7^{* *} \\ \text { Preferences } & (0.045) & \\ \text { Circuit Court } & 0.071^{*} & +0.8^{*} \\ \text { Preferences } & (0.037) & \\ \text { Gender } \mathbf{x} \text { Wars } & -0.145^{*} & -6.5^{*} \\ & (0.087) & \\ \text { Constant } & 0.392^{* *} & \\ & (0.039) & \\ \text { Wald } X^{2} & 1,516.7^{* *} & \\ \text { N } & 48,025\end{array}$

Entries are probit coefficients. Numbers in parentheses indicate robust standard errors. Dependent variable indicates the ideological direction of the decision $(1=$ conservative, $0=$ liberal). Model includes 53 region-specific dummy variables (results not shown). ${ }^{*} p<.05 ;{ }^{* *} p<$ .001 (one-tailed tests).

examine whether female judges respond differently than their male counterparts when evaluating disputes involving civil rights and liberties during wartime. If the above logic applies, we expect female judges will be more likely to support the civilrights-and-liberties claimant (i.e., render liberal decisions) during periods of international unrest, as compared to their male brethren.

To determine if male and female judges react differently to periods of international conflict, we estimate Model I in Table 1, with the addition of an interaction term between Wars and Gender. (We also examined if female and male jurists react differently to crises, as defined above. We find that crises do not influence the behavior of either group. As such, we examine only the influence of wars here.) Table 2 reports the empirical results. The estimate associated with the Wars variable reports the effect of wars for male jurists. The marginal effect indicates a statistically insignificant and substantively weak influence of war exists for male judges in federal district courts: less than 1 percent. The marginal effect for Gender illustrates the difference between male and female decision making when the nation is at peace. Consistent 


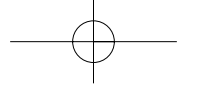

with Table 1, female judges are 2 percent more likely to render liberal decisions than their male counterparts. Of primary interest is the interaction term, Gender $\mathrm{x}$ Wars, which illuminates the multiplicative effect of wars on female judges' decision making. The marginal effect indicates that female jurists are 6.5 percent more likely to reject restrictions on civil rights and liberties during wartime as compared to peacetime. Thus, the conclusion can be drawn that male and female judges react differently to periods of international conflict. Specifically, male judges do not respond to periods of international unrest, while female judges are more likely to render liberal decisions during wartime. Thus, these results are consistent with the literature indicating a gender gap in attitudes toward wars. Moreover, these findings indicate that female judges treat prolonged periods of international war differently than short-term shocks to the nation's foreign affairs. This suggests that the severity of an international conflict, along with gender, is an important consideration when evaluating the judicial response to war. ${ }^{5}$

\section{CONCLUSIONS}

Scholars have long debated how foreign affairs influence the behavior of domestic actors. In this research, we have contributed to this literature by examining whether U.S. involvement in foreign conflicts alters the decision making of federal districtcourt judges. Consistent with the crisis thesis, we expected to find that judges alter their behavior during periods of international unrest by disposing of cases either more conservatively (since failure to do so may damage the government's ability to manage a crisis) or more liberally (in an effort to act as guardians of constitutional rights). Upon testing this argument in the federal district courts from 1938 to 2004, our evidence revealed that while female judges are more likely to render liberal decisions during wartime, male jurists do not exhibit a response to war. As such, our findings suggest that gender is an important consideration in evaluating the judicial response to war: although male judges continue on with business as usual, female jurists appear willing to act as guardians of constitutional rights, protecting individuals from a sometimes overzealous government. Further, this effect on female judges applies only to long-term foreign conflicts and is not applicable to short-term shocks to the nation's foreign affairs.

While we have tested the most common variation of the crisis thesis, we encourage future researchers to examine other facets of this paradigm regarding the federal district courts and other judicial venues. For example, one can logically extend the crisis thesis to the investigation of executive-branch success in these

5 Because the first female district-court judge was not appointed until 1949 (Burnita Matthews), we ran splitpopulation models (separating male and female judges), as well as a model that included a post-1949 dummy variable, to account for the fact that female judges did not serve on the district courts during World War II and served in limited capacity during the Korean War. Those results are consistent with the findings reported in Table 2. Note that, because women judges did not serve until 1949, the results appearing in Table 2 with respect to the influence of wars on female judges' decision making are limited to the Korean War, the Vietnam War, the Persian Gulf War, and the war in Afghanistan. 
courts, jury outcomes, or sentencing hearings. Indeed, if comments made by Judge William Young (D. MA.) are indicative of a more broadly held sentiment among federal jurists, the analysis of sentencing patterns might prove especially valuable. Further, analyses of specific issue areas are important in determining whether federal district-court judges are especially deferential to the government in, for example, freeexpression, search-and-seizure, or war-powers cases. Since our analyses focuses on a broad range of civil-rights-and-liberties cases, this research is limited in that it cannot speak to the influence of war on specific issue areas. We believe that such issuearea investigations are a fruitful avenue for future research since they allow researchers to control for pertinent case facts and vertical precedents that could prove relevant to district-court decision making. Moreover, since these results indicate that the influence of war on the district courts is significantly different from the courts of appeals (Clark, 2006) and the Supreme Court (Epstein et al., 2005), investigating the treatment of these cases throughout the judicial hierarchy is important in illuminating how different levels of the judiciary react to periods of international conflict. In addition to analyzing other aspects of federal decision making, scholars might also look to state courts for evidence of wartime influences. While the crisis thesis generally stresses federal civil-rights-and-liberties claims, states are often charged with implementing aspects of the federal government's crisis-related activities. Finally, we believe that examining the possibility of change over time will prove useful to illuminate whether factors related to, for example, American political development shape judicial decision making in wartime. Given that the significance of this question practically speaks for itself, future research into these, and other, unexamined areas will surely aid our understanding of how the nation's wartime activities reverberate throughout the entire judicial system. jsj

\section{REFERENCES}

Adler, D. G. (1996). "Court, Constitution, and Foreign Affairs.” In D. G. Adler and L. N. George (eds.), The Constitution and the Conduct of American Foreign Policy. Lawrence: University Press of Kansas.

Barak, A. (2002). "A Judge on Judging: The Role of a Supreme Court in a Democracy," 116 Harvard Law Review 16.

Baum, L. (1980). "Responses of Federal District Judges to Courts of Appeals Policies: An Exploration," 33 Western Political Quarterly 217.

Belluck, P. (2003). "Threats and Responses: The Bomb Plot," New York Times, January 31, p. 13.

Brambor, T., W. R. Clark, and M. Golder (2006). "Understanding Interaction Models: Improving Empirical Analyses," 14 Political Analysis 63.

Brecher, M., and J. Wilkenfeld (2004). International Crisis Behavior Project, 1918-2001. Fifth ICPSR version. College Park, MD: University of Maryland [producer]. Ann Arbor, MI: Inter-University Consortium for Political and Social Research [distributor]. 
Carp, R. A., and C. K. Rowland (1983). Policymaking and Politics in the Federal District Courts. Knoxville: University of Tennessee Press.

Carp, R. A., K. L. Manning, and R. Stidham (2004). "The Decision Making Behavior of George W. Bush's Judicial Appointments,” 88 Judicature 20.

Clark, T. S. (2006). "Judicial Decision-Making During Wartime," 3 Journal of Empirical Legal Studies 397.

Clarke, H. D., M. C. Stewart, M. Ault, and E. Elliot (2004). "Men, Women and the Dynamics of Presidential Approval," 35 British Journal of Political Science 31.

Conover, P. J., and V. Sapiro (1993). "Gender, Feminist Consciousness, and War,” 37 American Journal of Political Science 1079.

Cook, E., and C. Wilcox (1991). "Feminism and the Gender Gap: A Second Look," 53 Journal of Politics 1111.

Cooper, P. J. (1988). Hard Judicial Choices: Federal District Court Judges and State and Local Officials. New York: Oxford University Press.

Crockett, G. W. (1970). "Racism in Courts," 20 Journal of Public Law 685.

Department of Defense (2007). "Principal Wars in Which the United States Participated: U.S. Military Personnel Serving and Casualties," http://siadapp.dmdc.osd.mil/personnel/ CASUALTY/WCPRINCIPAL.pdf

Dietz, M. G. (1985). "Citizenship with a Feminist Face: The Problem with Maternal Thinking," 13 Political Theory 19.

Downs, D. A., and E. Kinnunen (2003). "A Response to Anthony Lewis: Civil Liberties in a New Kind of War," Wisconsin Law Review 385.

Ducat, C. R., and R. L. Dudley (1989). "Federal District Judges and Presidential Power During the Postwar Era," 51 Journal of Politics 98.

Duggan, W. D. (2005). "Palmer-Do Not Let this Country See Red," Albany County Bar Association Newsletter, February, p. 10.

Edwards, G. C., III. (1976). "Presidential Influence in the House: Presidential Prestige as a Source of Presidential Power," 70 American Political Science Review 101.

Epstein, L., D. E. Ho, G. King, and J. A. Segal (2005). "The Supreme Court During Crisis: How War Affects Only Non-War Cases," 80 New York University Law Review 1.

Erikson, R. S., N. R. Luttbeg, and K. L. Tedin (1980). American Public Opinion. 2nd ed. New York: Wiley.

Fleisher, R., and J. R. Bond (1988). "Are There Two Presidencies? Yes, But Only for Republicans," 50 Journal of Politics 747.

Fleisher, R., J. R. Bond, G. S. Krutz, and S. Hanna (2000). "The Demise of the Two Presidencies," 28 American Politics Research 3.

Fortas, A. (1968). Concerning Dissent and Civil Disobedience. New York: New York World Publishing.

Franck, T. M. (1992). Political Questions/Judicial Affairs: Does the Rule of Law Apply to Foreign Affairs? Princeton, NJ: Princeton University Press. 
Friedman, L., and B. Neuborne (1972). Unquestioning Obedience to the President: The ACLU Case Against the Legality of the War in Vietnam. New York: Norton.

Gartner, S. S., G. M. Segura, and B. Barratt (2004). "War Casualties, Policy Positions, and the Fate of Legislators," 53 Political Research Quarterly 467.

Garvin, M. A. (1999). "Civil Liberties During War: History's Institutional Lessons,” 16 Constitutional Commentary 691.

Gelpi, C. (1997). "Democratic Diversions: Governmental Structure and the Externalization of Domestic Conflict," 41 Journal of Conflict Resolution 255.

Gilligan, C. (1982). In a Different Voice: Psychological Theory and Women's Development. Cambridge: Harvard University Press.

Goldstein, J. S. (2001). War and Gender: How Gender Shapes the War System and Vice Versa. Cambridge: Cambridge University Press.

Gourevitch, P. (1978). "The Second Image Reversed: The International Sources of Domestic Politics," 32 International Organization 881.

Gross, O. (2003). "Chaos and Rules: Should Responses to Violent Crises Always Be Constitutional?," 112 Yale Law Journal 1011.

Gruhl, J., C. Spohn, and S. Welch (1981). "Women as Policymakers: The Case of Trial Judges," 25 American Journal of Political Science 308.

Gryski, G. S., E. C. Main, and W. J. Dixon (1986). "Models of State High Court Decision Making in Sex Discrimination Cases," 48 Journal of Politics 143.

Heymann, P. B. (2002). "Civil Liberties and Human Rights in the Aftermath of September 11," 25 Harvard Journal of Law and Public Policy 441.

Hinckley, B. (1994). Less Than Meets the Eye: Foreign Policy Making and the Myth of the Assertive Congress. Chicago: University of Chicago Press.

Keohane, R. O. (1989). "International Relations Theory: Contributions of a Feminist Standpoint," 18 Millennium 245.

King, K. L., and J. Meernik (1999). "The Supreme Court and the Power of the Executive: The Adjudication of Foreign Policy," 52 Political Research Quarterly 801.

Klinkner, P. A., and R. M. Smith (1999). The Unsteady March: The Rise and Decline of Racial Equity in America. Chicago: University of Chicago Press.

Koh, H. H. (2002). "The Spirit of Laws," 43 Harvard International Law Journal 23.

— (1996). "Why the President Almost Always Wins in Foreign Affairs." In D. G. Adler and L. N. George (eds.), The Constitution and the Conduct of American Foreign Policy. Lawrence: University Press of Kansas.

Lian, B., and J. R. Oneal (1993). "Presidents, the Use of Military Force, and Public Opinion," 37 Journal of Conflict Resolution 277.

Linfield, M. (1990). Freedom Under Fire: U.S. Civil Liberties in Times of War. Boston: South End Press.

Lobel, J. (2002). "The War on Terrorism and Civil Liberties," 63 University of Pittsburgh Law Review 767. 
Manning, K. L., B. A. Carroll, and R. A. Carp. (2004). "Does Age Matter? Judicial Decision Making in Age Discrimination Cases," 85 Social Science Quarterly 1.

May, C. N. (1989). In the Name of War: Judicial Review and the War Powers Since 1918. Cambridge: Harvard University Press.

Mecham, L. R. (2005). "Judicial Business of the United States Courts." http://www.uscourts. gov/judbususc/judbus.html

Meernik, J. (1993). "Presidential Support in Congress: Conflict and Consensus on Foreign and Defense Policy," 55 Journal of Politics 569.

Mueller, J. E. (1970). "Presidential Popularity from Truman to Johnson," 64 American Political Science Review 18.

Neely, M. E. (1992). The Fate of Liberty: Abraham Lincoln and Civil Liberties. New York: Oxford University Press.

Nelson, L. (2004). "Privacy and Technology: Reconsidering a Crucial Public Policy Debate in the Post-September 11 Era," 64 Public Administration Review 259.

Nincic, M., and D. J. Nincic (2002). "Race, Gender, and War," 39 Journal of Peace Research 568.

Oneal, J. R., and A. L. Bryan (1995). "The Rally 'Round the Flag Effect in U.S. Foreign Policy Crises, 1950-1985,” 17 Political Behavior 379.

Page, B. I., and R. Y. Shapiro (1992). The Rational Public: Fifty Years of Trends in Americans' Policy Preferences. Chicago: University of Chicago Press.

Peresie, J. L. (2005). "Female Judges Matter: Gender and Collegial Decision Making in the Federal Appellate Courts," 114 Yale Law Journal 1759.

Peterson, P. E. (1994). “The President's Dominance in Foreign Policy Making,” 109 Political Science Quarterly 215.

Peterson, V. S. (1992). Gendered States: Feminist (Re)Visions of International Relations Theory. Boulder, CO: Lynne Reinner.

Pinello, D. R. (1999). "Linking Party to Judicial Ideology in American Courts: A MetaAnalysis," 20 Justice System Journal 219.

Prins, B. C., and B. W. Marshall (2001). "Congressional Support of the President: A Comparison of Foreign, Defense, and Domestic Policy Decision Making During and After the Cold War," 31 Presidential Studies Quarterly 660.

Randazzo, K. A. (2004). "Foreign Affairs Litigation in the U.S. Courts of Appeals: A Preliminary Analysis," 25 Justice System Journal 227.

Rehnquist, W. H. (1998). All the Laws But One. New York: Alfred A. Knopf.

Robinson, G. (2001). By Order of the President: FDR and the Internment of Japanese Americans. Cambridge: Harvard University Press.

Rossiter, C. L. (1976). The Supreme Court and the Commander in Chief. Ithaca, NY: Cornell University Press.

Rostow, E. (1945). “The Japanese American Cases_A Disaster,” 54 Yale Law Journal 489. 
Rowland, C. K., and R. A. Carp (1996). Politics and Judgment in Federal District Courts. Lawrence: University of Kansas Press.

Rudenstine, D. (1996). The Day the Press Stopped: A History of the Pentagon Papers Case. Berkeley: University of California Press.

Russett, B. (1990). Controlling the Sword: The Democratic Governance of National Security. Cambridge: Harvard University Press.

Schafran, L. H. (2005). "Not from Central Casting: The Amazing Rise of Women in the American Judiciary," 36 University of Toledo Law Review 953.

Shapiro, R. Y., and H. Mahajan (1986). "Gender Differences in Policy Preferences: A Summary of Trends from the 1960's to the 1980's," 50 Public Opinion Quarterly 42.

Schubert, G. (1965). Judicial Policy Making. Chicago: Scott, Foresman and Company.

Schultz, K. (1998). "Domestic Opposition and Signaling in International Crises," 92 American Political Science Review 829.

Segal, J. A., and H. J. Spaeth (1993). The Supreme Court and the Attitudinal Model. Cambridge: Cambridge University Press.

Segal, J. A., R. J. Timpone, and R. M. Howard (2000). "Buyer Beware? Presidential Success Through Supreme Court Appointments," 53 Political Research Quarterly 557.

Sisk, G. C., M. Heise, and A. P. Morriss (2004). "Searching for the Soul of Judicial Decisionmaking: An Empirical Study of Religious Freedom Decisions," 65 Ohio State Law Journal 491.

— (1998). "Charting the Influences on the Judicial Mind: An Empirical Study of Judicial Reasoning," 73 New York University Law Review 1377.

Solberg, R. L. S., and K. A. Bratton (2005). "Diversifying the Federal Bench: Presidential Patterns," 26 Justice System Journal 119.

Songer, D. R. (1999). The United States Courts of Appeals Data Base, Phase I. Columbia: Department of Political Science, University of South Carolina.

Songer, D. R., and K. A. Crews-Meyer (2000). "Does Gender Matter? Decision Making in State Supreme Courts,” 81 Social Science Quarterly 750.

Songer, D. R., J. A. Segal, and C. M. Cameron (1994). "The Hierarchy of Justice: Testing a Principal-Agent Model of Supreme Court-Circuit Court Interactions," 38 American Journal of Political Science 673.

Spaeth, H. J. (2003). The Original United States Supreme Court Database, 1953-2001 Terms. East Lansing: Department of Political Science, Michigan State University.

Swenson, K. (2004). "Federal District Court Judges and the Decision to Publish," 25 Justice System Journal 121.

Sylvester, C. (1994). Feminist Theory and International Relations in a Postmodern Era. Cambridge: Cambridge University Press.

Tushnet, M. (2003). "Defending Korematsu?: Reflections on Civil Liberties in Wartime," Wisconsin Law Review 273. 
Vasquez, J. A. (1987). "The Steps to War: Towards a Scientific Explanation of Correlates of War Findings," 40 World Politics 108.

Welch, S., M. Combs, and J. Gruhl (1988). "Do Black Judges Make a Difference?,” 32 American Journal of Political Science 126.

Wilcox, C., L. Hewitt, and D. Alsop (1996). "The Gender Gap in Attitudes Toward the Gulf War: A Cross-National Perspective," 33 Journal of Peace Research 67.

Wildavsky, A. (1966). "The Two Presidencies," 4 Trans-Action 7.

Yates, J., and A. Whitford (1998). "Presidential Power and the United States Supreme Court," 51 Political Research Quarterly 539.

\section{Cases Cited}

Ex Parte Merryman, 17 F. Cas. 144 (C.C. MD. 1861).

Ex Parte Milligan, 71 U.S. 2 (1866).

Gobitis v. Minersville School District, 21 F. Supp. 581 (E.D. PA. 1937).

Grzywna v. Schenectady Central School District, 489 F. Supp. 2d 139 (N.D. N.Y. 2006).

Hodsdon v. Buckson, 310 F. Supp. 528 (D. DE. 1970).

Hohri v. United States, 586 F. Supp. 769 (D. D.C. 1984).

Khalid v. Bush, 355 F. Supp. 2d 311 (D. D.C. 2005).

Korematsu v. United States, 323 U.S. 214 (1944).

Morris v. Khadr, 415 F. Supp. 2d 1323 (D. UT. 2006).

Padilla v. Hanft, 389 F. Supp. 2d 678 (D. S.C. 2005).

Schenck v. United States, 249 U.S. 47 (1919).

United States v. Herberger, 272 F. 278 (W.D. WA. 1921).

United States v. Koubriti, 305 F. Supp. 2d 723 (E.D. MI. 2003).

United States v. Mulligan, 268 F. 893 (N.D. N.Y. 1920).

West Virginia v. Barnette, 319 U.S. 624 (1943). 


\section{Appendix \\ Variable Definitions and Summary Statistics}

Dependent Variable Captures the ideological direction of the decision. 1 = conservative decision, 0 = liberal decision.

Mean $=0.643 \quad$ Standard Deviation $=0.479$

Wars

1 = Case was decided during World War II, Korean War, Vietnam War, Persian Gulf War, or war in Afghanistan, 0 = otherwise.

Mean $=0.199 \quad$ Standard Deviation $=0.399$

Crises

Party

1 = Case was decided during Berlin Blockade, Cuban Missile Crisis, Iran-Hostage Crisis, or War on Terror, $\mathrm{O}=$ otherwise.

Mean $=0.102 \quad$ Standard Deviation $=0.303$

1 = Judge was appointed by Republican President, 0 = Judge was appointed by Democratic President.

Mean $=0.485 \quad$ Standard Deviation $=0.500$

Gender

$1=$ Female judge, 0 = Male judge.

Mean $=0.069 \quad$ Standard Deviation $=0.254$

Minority $1=$ Judge is African-American, Asian-American, Hispanic, or Native American, $\mathrm{O}=$ otherwise.

Mean $=0.079 \quad$ Standard Deviation $=0.269$

Supreme Court Preferences

Circuit Court

Preferences

Gender x Wars
The proportion of Supreme Court justices appointed by Republican Presidents.

Mean $=0.643 \quad$ Standard Deviation $=0.177$

The proportion of court-of-appeals judges appointed by Republican presidents serving on the supervisory circuit pertinent to each district court.

Mean $=0.552 \quad$ Standard Deviation $=0.200$

An interaction term created by multiplying the Gender and Wars variables. The marginal effect of this interaction term, reported in Table 2, was calculated using the method developed by Brambor, Clark, and Golder (2006).

Mean $=0.005 \quad$ Standard Deviation $=0.070$ 